\title{
Indonesia Debt to Equity Ratio (DER) Policy of Listed Companies on International Taxation Best Practices
}

\author{
Maria R.U.D. Tambunan ${ }^{1}$, Ginda Togatorop ${ }^{2}$, Sabila Mareli ${ }^{3}$ \\ maria.tambunan@ui.ac.id ${ }^{1}$,ginda.simakui@gmail.com², sabilam9@gmail.com³ \\ Faculty of Administrative Science Universitas Indonesia ${ }^{1,2,3}$
}

\begin{abstract}
The aims of this article are to examine whether Debt-to-Equity Ratio (DER) Policy in Indonesia has been fair on international tax best practices, to assess the practices of DER for listed companies in Indonesia Stock Exchange (ISE) and to identify the types of industries need to further review of their financing schemes that potentially would risk on their completion of tax obligation. This research occupies qualitative method. The data was gathered through literature review and documentation study. The research shows that the DER of listed companies in ISE for most of sectors are still below the Indonesia DER threshold, with mining industry close to the threshold. Indonesia DER is still moderate compare to other countries which adopt the similar approach. For further study, it needs to assess the non-listed companies whether the Indonesia threshold is still appropriate
\end{abstract}

Keyword: Debt-to-equity ratio, arm's length, listed companies, interest expenses, related party.

\section{Introduction}

The aim of this article is to examine whether Debt-to-Equity Ratio (DER) Policy in Indonesia has been fair enough on taxation perspective if it is reflected on international best practices. In addition, this article also intended to assess the practices of debt to equity ratio for several industries performed by listed companies in Indonesia Stock Exchange, then to identify the types of industries need to further review of their financing schemes that potentially would risk on their completion of tax obligation.

Indonesia, a developing countries with abundant of resources had to invite the foreign investor to bring the capital, technology and knowledge in order to create the added value on its resources and to produce the multiplier effect on national economic development. On the other hand, the government also has to set the rule to ensure the investors fulfill their investment commitment in bring their capital to be invested in Indonesia. Indonesia Investment Coordinator Board published that the foreign investor has to accomplish the investment commitment, as mentioned on Indonesia Investment Law No. 25/ 2007 on General Elucidation Paragraph (2) "In connection therewith, investments must be made a part of the conduct of national economy and be positioned in an effort to increase the national economic growth, to create job opportunities, to improve sustainable economic development, to improve the capacity and capability of national technology, to foster people's economic development, as well as to realize public welfare, in a competitive economic system" . Further, the government also has to able ensure their compliance with tax regulation.

In fact, Media Indonesia in April 2016 reported that more than 2.000 foreign business did not paid the corporate income tax for the last 10 year consecutively due to profit lost [1]. 
Similarly, Head of Indonesia Investment Coordinator Board also said that Indonesia has lost its revenue about IDR 500 trillion within these 10 years [2]. It means that the business entities has operated sustainably for 10 years and expanded the business the but they could not generate the profit. On this point of view, it seems that the idea of inviting investors has not had met the multiplier economic effects. This problem might be added by numbers of loopholes exploited by the business to abuse tax obligation.

With regards to assess whether the business performed aggressive tax planning or tax avoidance, it can be examined through how business entities inject the fund by optimizing kinds of financing schemes. For funding injection, business may look for debt or capital injection from shareholders [3]. It seems that the idea whereas investor should bring the capital instead of debt also has not been fulfilled. While injecting debt for financing, as a consequence, business entities will pay interest for the debt source entity that is deductible for calculation of corporate income tax obligation purpose. Whereas, if the shareholders inject the capital as the equity, business entity will pay the dividend as the exchange of capital funding injection based on the ownership percentage. However, the dividend is not categorized deductible expenses against the profit.

The problem arised when hybrid financing scheme performed, that shareholders inject capital financing as if it is debt financing or by other financing schemes; the business get huge money in form of debt from related parties through direct loan, back to back loan and parallel loan. These practices are commonly called as thin capitalization [4]. It means, for the tax purpose, getting equity through debt financing is a preferable measure than that of capital financing since the excessive interest paid can be calculated as deductible expenses to erode the profit as the base calculation for income tax payable. With this low cost of capital scheme, the business entity will not be paid corporate income tax or will pay on very low.

Even though Indonesia has reformed fundamentally its tax system since 1983, Debt to Equity Ratio (DER) regulation to tackle thin capitalization practice was stipulated in September 2015 through Ministry of Finance Regulation No. 169/PMK.010/2015 (PMK-169). Before September 2015, Indonesia domestic regulation allowed multinational enterprise to finance its subsidiary or intra-group entities in Indonesia by injecting capital equity or debt without strict limitation even though for particular industry such as banking industry, insurance, re-insurance and financing, that for them, specific exception applied. For business entity which seek for the highest return, they would tend to optimize paying interest to related party in exchange of debt equity or as a form of profit transfer. For multinational business entities, recalling the weighted average cost of capital, these opportunities probably would be optimized by them to shifting the profit under cross-jurisdiction financing through types of debt financing schemes [5].

Currently, many countries have implemented domestic regulation to limit the excessive interest payment by setting the certain ratio or other interest limitation rule. Further, OECD with its Base Erosion and Profit Shifting (BEPS) project has covered the alternative measure to tackle these practices by recommending the members to set the debt limit [6]. This article will examine the Indonesia tax regulation of debt to equity ratio since it has been stipulated at the first time until currently. However, it needs to highlight that the assessment made to listed companies in Indonesia Stock Exchange. This segmentation is made due to the availability and sufficiency of reliable information. This article also is aimed to assess whether it has been formulated as how most of countries has regulated. Finally, the article is also intended to point out type of industry need to monitor potentially lead to aggressive tax planning 


\section{Research Method}

The approach used in this study is a qualitative approach. This approach aims to provide understanding and interpretation of a social phenomenon by direct observation. One of the characteristics of research with a qualitative approach is not value-free, meaning that the research process can be influenced by a variety of values and subjective income. Furthermore, the theory used in this approach is not a central thing, but only as a basic framework for conducting the process of analyzing data based on findings in the field. Thus, the theory does not become a verification item because it is only supporting in the analysis process when going to the field.

This research was conducted in the period from July 2019 to September 2019. In terms of objectives, this study is a descriptive research. Descriptive research is research that in detail describes social phenomena. The purpose of this study is to illustrate the implementation of the provisions related to the Debt-to-Equity Ratio in Indonesia carried out by several sector, especially since the issuance of PMK-169/2015 which regulates the related ratio of debt and equity in Indonesia. Data collection techniques were carried out using qualitative data collection techniques, namely through literature studies and documentation studies. The data collected consists of secondary data which consists of various publication information by Indonesian tax authorities, tax consultants and mass media.

\subsection{Result: Taxation Aspect on Debt Equity Financing}

The aim of capital owner to invest through foreign investment is that to transfer the tangible assets and/or intangible assets from one jurisdiction to other jurisdiction to generate higher return through modes of business entities operated on the investment location under wholly or partly the principal control owner of the assets [7]. The classical premises of equity investment means the involvement on more permanent capital whereas the risk of loss is exchange for the rights to control, undertake and participate on the business [8]. On the other side, investing by injecting equity means the equity owners participate to anticipate the risk of loss due to low quality business performance that immediately affect the potential of low return. On the different condition, when the investment made on the form of debt, the debtor would bear the interest expenses which possibly affect the contingency of business performance. Therefore, it could be said that the business risk by investing on debt and equity would not be equal. The difference between equity and ratio could be described as follow:

Table 1. The Difference between Equity and Debt Financing

\begin{tabular}{lll}
\hline Aspects & Equity & Debt \\
\hline Income & Dividend & Interest \\
The principle of tax treatment & Dividend is not deductible & Interest is deductible as \\
\hline
\end{tabular}




\begin{tabular}{lll}
\hline Control of ownership & against revenue & $\begin{array}{l}\text { expenses against } \\
\text { revenue } \\
\text { The control of funding } \\
\text { injector is limited } \\
\text { based on the agreement } \\
\text { The equity owner has voting } \\
\text { rights }\end{array}$ \\
$\begin{array}{ll}\text { The investor could not enforce } \\
\text { the business on bankruptcy status } \\
\text { solely due to inability to }\end{array}$ & $\begin{array}{l}\text { If the lender could not } \\
\text { pay the interest } \\
\text { expenses, the entities } \\
\text { distribute dividend }\end{array}$ & $\begin{array}{l}\text { could be enforced on } \\
\text { bankruptcy situation }\end{array}$ \\
\hline
\end{tabular}

Source: Ross et. Al (2010) citing from Hartono (2014) [18]

Besides the explanation on table above, the most common distinction on both of investment schemes debt-equity is the financing issue. Following their legal character, it has different inherent character on the liability. It can be contrasted between the entity which engaged in the business (equity) and entity that engaged in an independent business by undertaking of leading to the business (debt). Because of this contrast engagement relation, it will be absolutely affecting the profit sharing as the result of the difference of deductibility treatment. A well-known cited description of the distinction underlies in terms of risk exposure is as followed:

The essential difference between a stockholder and a creditor is that the stockholder's intention is to embark upon the corporate adventure, taking the risk of loss attendant upon it, so that he may enjoy the chances of profit. The creditor, on the other hand, does not intended to take such risk so far as they may be avoided, but merely to lend his capital to others who do intend to take them.

Referring to [9] the injection of equity into an entity the financing party would admit the all the consequence of business risk, including the postponement of distribution of business return. On the other hand, the loan in fact is an advance financing with less risk even though the financing party could be possible to convert the amount of lend into equity due to the potential high return of business. The conventional view is that the debt-equity distinction represents a difference in kind in terms of risk exposure. The main modern challenge to that view is that debt and equity are functionally or economically equivalent and therefore are not different in kind.

However, whether the foreign investor or multinational enterprises on large proportion "really" invest the capital on their business located in the intended jurisdiction has been still questionable. For prominent multinational enterprise, they should have a good access to financing entities or financing market whether it is debt or equity, thus they should not face difficulties to inject the fund for them under common control business. Therefore, it probably can be said that the financing scheme will ultimately be determined by type of financing scheme generating highest return [10].

On conceptual perspective, debt financing for the purpose of thin capitalization can be performed through three well-known method, illustrated as follow [11]:

a. Direct loan; A subsidiary of other foreign parent company incorporated in Indonesia (PT. PMA) earned debt equity from its parent has get lost for several consecutive years. To sustain the business operation, parent company continuously inject debt capital, not paid up capital. As a consequence, the subsidiary as to pay interest for the parent company located in different jurisdiction. The interest paid is treated as deductible expenses for the purpose of corporate income tax calculation. Continuous 
debt injection will restructure equity proportion. Based on empirical research in 2010, more than $50 \%$ of foreign company has more than $3: 1$ debt to equity ratio.

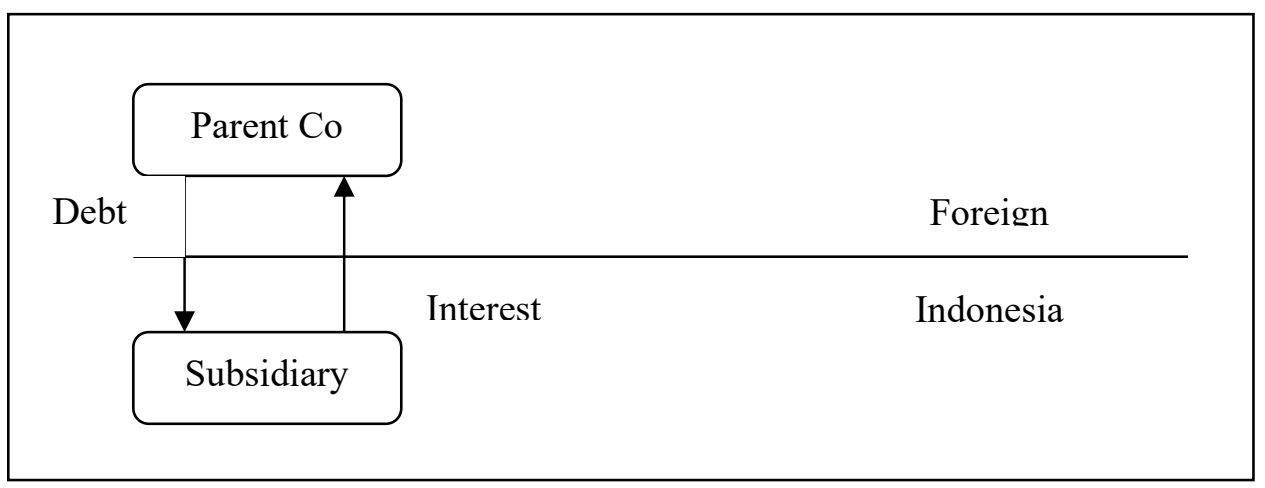

Fig. 1. Direct Loan Scheme

b. Parallel loan; Foreign parent company (X Ltd.) indirectly inject debt capital to its subsidiary in Indonesia (PT. X). For the parallel load financing scheme, X Ltd funded in the form of debt to PT. Y in Indonesia. Then Y Ltd provided debt to be transferred to PT. X, PT Y is the subsidiary of Y Ltd in Indonesia. X Ltd and Y Ltd are the entity under common control or related party.

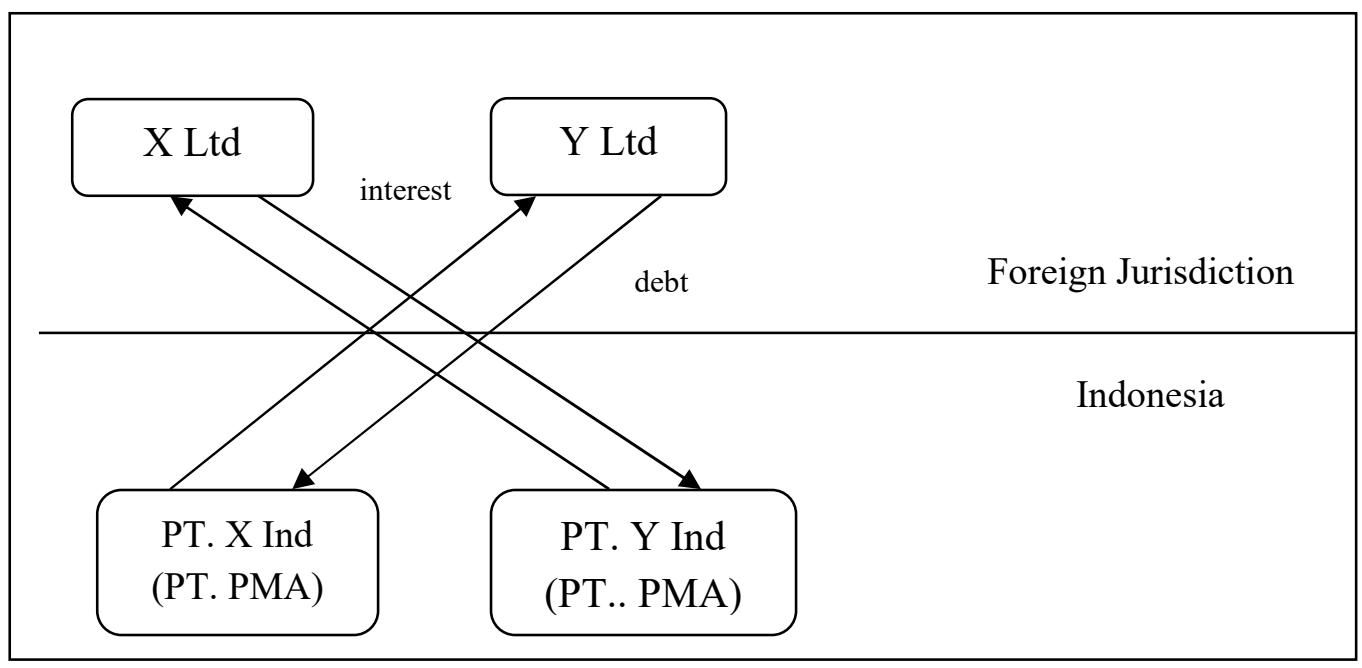

Fig 2. Parallel Loan Scheme

c. Back to back loan; through this scheme, foreign parent company indirectly inject debt equity to the subsidiary in a particular country through particular intermediary entities. Parent company deposit the money on the bank, for example in Indonesia, then the bank transferred the fund to Indonesia subsidiary (PT. PMA). As a consequence, PT. PMA has to pay interest to the bank. For tax planning purpose, this scheme is tend to more prudent to minimize income tax payable since tax authority has limted access to trace the debt scheme considering the role of bank as an 


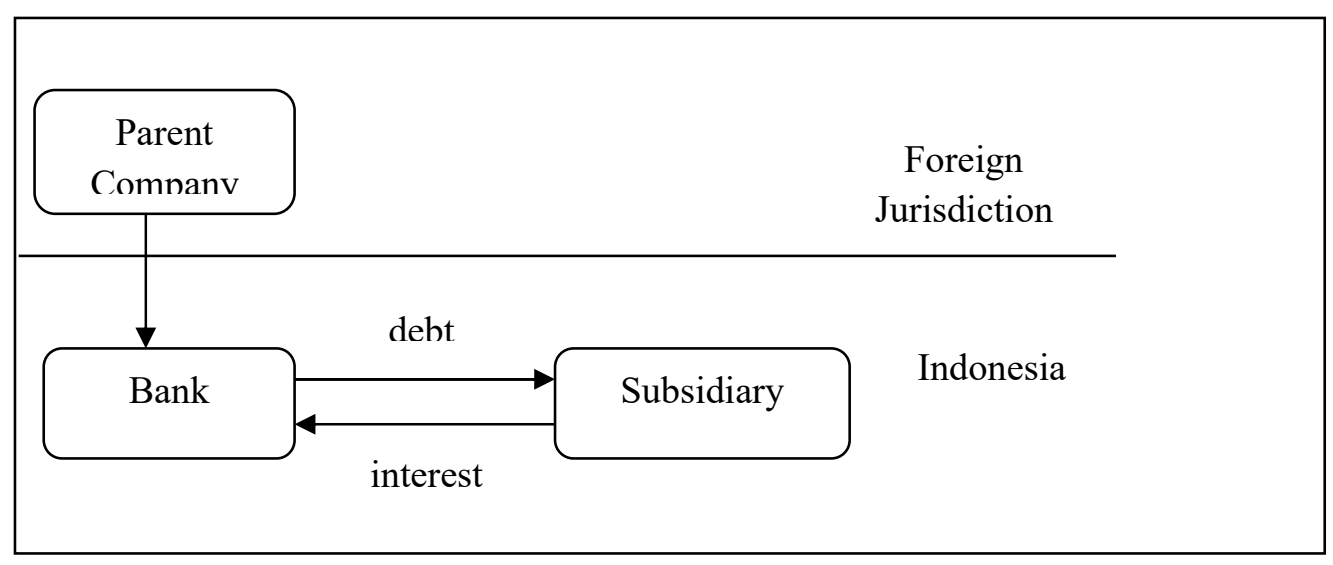

Fig 3. Back-to-back Loan Scheme (1)

Besides the back-to-back loan scheme above, another possible back-to-back loan scheme is as followed.

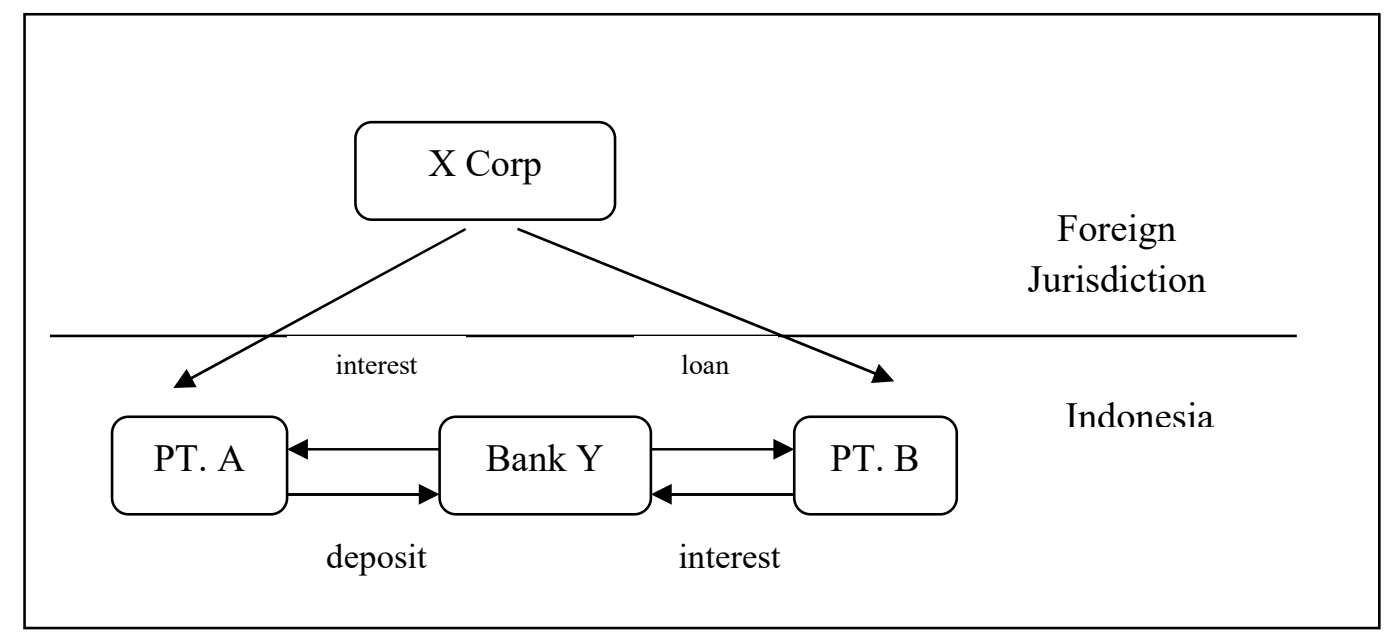

Fig. 4 Back-to-back Loan Scheme (2)

PT. A (PMA) and PT. B are under common control of X Corp located in foreign jurisdiction. Back-to-back loan scheme is performed intra-group between two X Corp's subsidiary. PT A deposit its money on Bank Y then the money will be transferred to PT. B. In many cases, parent company which lend the money use its authority to charge the interest rate to the subsidiary. It means the interest rate could be higher than the market interest rate or debt without interest. For particular country like Indonesia, parallel loan scheme and back-to-back loan has been still challenging enough to assess due to its complicated transaction nature, then added by insufficient regulation to tackle thin capitalization practices.

Classical guideline released by OECD on its OECD Report on Thin Capitalization 1987 emphasize several tax aspects need to scrutinized as the impact of excessive debt financing scheme [12].

1. Tax efficiency is a result of debt financing which enable the business to add deductible expenses on calculating income tax payable.

2. Tax efficiency will be higher if the creditor is subjected to lower tax rate or free tax. 
3. Base erosion of tax potential revenue will be higher on source country if the interest is paid to other jurisdiction where tax rate is lower.

4. Debt financing equity may be get from entities incorporated in tax haven countries.

5. Excessive debt financing finally will abuse the principle of foreign direct investment

To minimize the practices of thin capitalization or profit shifting through debt schemes, most of the countries has regulated the threshold of debt-to-equity ratio [13]. Several well-known method to assess whether the proportion of debt financing still acceptable under prevailing law on particular countries consist of (i) debt-to-equity ratio, (ii) interest to EBITDA ratio and (3) arm's length principle [14],

a. debt-to-equity ratio (DER); this concept is used to limit the ratio of debt on total equity thus the amount of interest paid to the borrowed entities should be similar to the set ratio. If the debt-to-equity ratio has been determined $2: 1$, it means the total of interest paid should be no more than 2:1. This method is the most simple way and most commonly used by the tax authority to assess the acceptable rate of debt financing [15]. However, as the drawback, constant and precise debt to equity ratio cannot figure out the dynamic of business [16]. Further, for particular industry, for instance, banking industry and other financial services specific exemption should be applied considering their main business as financing intermediary which the liquity performance will be leverage factor for their business.

b. interest to EBITDA (Earnings Before Interest Tax, Depreciation and Amortization) ratio; commonly known as earning stripping approach. The premises of this approach are to assess the amount of interest paid on relation to the income generated from the debt financing [17]. It means this tools objective is to prevent the excessive deductible expenses on the interest payment without direct correlation on the business activities, such as intra-group payment. In 2016, 86 countries around the world have implemented EBITDA to limit the interest payment. EBITDA approach can be more precisely show the business dynamic situation of enterprises compare to DER approach. On the other hand, when the enterprise is on the downturn situation where it needs to get loan from other entities to recover the lost, the enterprise will tend to face more challenging situation due to EBITDA rule.

c. arm's length principle; this method refers to the market situation whereas the assessment objective is to identify whether the interest rate charged for intra-group or related party loan is similar if the loan gets from independent party. This approach was constructed due to the fact that prolifically unfair interest charge performed by intra-group entity. However, assessing the interest payment fairness by using this method is not simple since it needs to find the comparable data in order to examine the transaction fairness.

The limitation to the interest as the consequence of debt financing could be categorized into two schemes. The first scheme is a "stand-alone" approach and a "worldwide" ratio approach. On the stand-alone approach, it will assess how much financing debt could be undertaken by the subsidiary from the third party if the subsidiary is treated as a single independent entity instead of as a member of corporate group. This status consequently will affect the rate of interest charged. Under the world-wide ratio approach, the total debt financing injected by the third party would be calculated as the multinational corporate group loan. Then, for the purpose of ratio calculation, the total of loan is allocated to each of subsidiary located in various jurisdiction. In practical aspect, both types are combined or has been adopted as a hybrid method by pairing a fixed debt-to-capital or interest-to-profit ratio with an arm's length interest rate [15]. Brunett suggested that to weigh up the current available 
approaches and to make consideration in determining the chosen policy with regard to debt equity financing, the it need to analyze four propositions [15]:

a. Capital injection through intra-group debt or corporate group debt is a close or perfect substitute for equity swap

b. A subsidiary of a corporate group has an identifiable arm's length amount of debt and an intra-group loan has an identifiable arm's length price

c. Tax burden might be an important consideration in determining the corporate group choice for its third-party debt.

d. For tax purposes, the leverage level of a multinational corporate group should be similar on its interest group on each jurisdiction where it run its business.

In fact, each country has different rules to tackle the excessive interest payment. Despite the variability, most countries' rules would be put on the range of stand-alone entity approach and a worldwide ratio approach. Essentially, under the stand-alone approach, it considers that the leverage and interest rate should be the entity level, or it means the level is on the local subsidiary. Further, the next questions need to address are that the among of load could be get, the rate of interest and how to assess the fulfilment of arm's length principle. These questions are identic to the queries which referred to the thin capitalization concept suggested by OECD to calculate the deductions of a branch relative to the head office, based on a transfer pricing functional analysis. Commonly, the stand-alone approaches still take account of the fact that the subsidiary belongs to a multinational group. On the other hand. The difference condition might be acceptable, such as that in the United Kingdom imposes a more stringent "stand-alone" assumption, hypothesizing away the parent and any subsidiaries companies.

In contrast, the worldwide approach firstly will consolidate the group, measure the third-party leverage ratio and interest cost. This leverage ratio is then compared to the leverage ratio of the local subsidiary; if the latter is higher than debt deductions are disallowed to that extent. Another way of achieving this outcome is by disregarding all intra-group debt and notionally spreading the total third-party interest deductions amongst the multinational's jurisdictions according to assets, regardless of where the interest is actually incurred.

\subsection{Discussion: Thin Capitalization Rule and Assessing Debt to Equity Ratio on Several Industries in Indonesia}

Indonesia Investment Law No. No. 25/ 2007 Art. 1 Par. 3 mentioned that "Foreign Investment means an investing activity to do business in the territory of the state of the Republic of Indonesia that is carried out by a foreign investor both by use of all of foreign capital and by engagement in a joint venture with a domestic investor. This regulation highlights two important aspects, first foreign investment can be a form of joint venture of domestic capital owner with foreign capital owner to establish a business entity. Second, foreign entities bring the capital wholly to be invest in Indonesia. Therefore, the initial concept of investment is that run the business by injecting the capital equity not by injecting excessive debt.

Actually, Indonesia Income Tax Law in 1983 as mentioned in Article 18 paragraph 1 has mandated the government to set the rule on debt limitation to equity. Then, as the technical guidance, Ministry of Finance Stipulation No. 1002/KMK.04/1984 regarding Determination of Debt to Equity Ratio had been released. This regulation was becoming the 
guideline to determine the limitation of debt to the equity 3:1 except trading debt. However, this regulation was cancelled by the released of Ministry of Finance Stipulation No. 254/KMK.01/1985. It means almost 30 years Indonesia had not has clear regulation about this issue. Therefore, it can be said that lack of regulation could be exploited as a loophole. In 2015, the government released Ministry of Finance Regulation No.169/PMK.01/2015 (PMK169) dated 9 September 2015 concerning Stipulation of Debt and Equity Ratio for Income Tax Calculation Purpose. Before 2015, the Head Office Indonesia Tax Authority, Directorate General of Taxation (DGT) found out more than $50 \%$ corporate taxpayer registered in Large Taxpayer Office had practiced thin capitalization by constructing loss scenario to avoid paying taxes. The milestone of Indonesia thin capitalization since 1983 rule can be described as follow:

Table 2. Indonesia Thin Capitalization Rules

\begin{tabular}{|c|c|c|}
\hline $\begin{array}{l}\text { Ministry of Finance } \\
\text { Stipulation No. } \\
\text { 1002/KMK.04/1984 } \\
\text { (KMK-1002) } \\
\end{array}$ & $\begin{array}{c}\text { Ministry of Finance Stipulation } \\
\text { No. 254/KMK.01/1985 } \\
\text { (KMK-245) }\end{array}$ & $\begin{array}{c}\text { Ministry of Finance Regulation } \\
\text { No. 169/PMK.10/2015 } \\
\text { (PMK-169) }\end{array}$ \\
\hline $\begin{array}{l}\text { Concerning Limitation of } \\
\text { Debt to Equity Ratio for } \\
\text { Income Tax Calculation } \\
\text { Purpose }\end{array}$ & $\begin{array}{l}\text { Concerning Cancelation of } \\
\text { Ministry of Finance } \\
\text { Stipulation No. } \\
\text { 1002/KMK.04/1984 }\end{array}$ & $\begin{array}{l}\text { Concerning Limitation of Debt to } \\
\text { Equity Ratio for Income Tax } \\
\text { Calculation Purpose }\end{array}$ \\
\hline $\begin{array}{l}\text { DER } 3: 1 \text { except debt due to } \\
\text { trading transaction }\end{array}$ & & $\begin{array}{l}\text { DER } 4: 1 \text { several exceptions apply to } \\
\text { the business entities (PwC, 2015): } \\
\text { 1. bank } \\
\text { 2. financing institutions } \\
\text { 3. insurance and reinsurance } \\
\text { companies } \\
\text { 4. taxpayers in oil and gas mining, } \\
\text { general mining, other mining } \\
\text { companies under a Production } \\
\text { Sharing Contract (PSC), Contract } \\
\text { of Work (CoW), Mining } \\
\text { Cooperation Agreement, and the } \\
\text { relevant contract/agreement } \\
\text { contains provision governing } \\
\text { DER. If the contract/agreements } \\
\text { do not contain the provision, or } \\
\text { the contract has expired, the } \\
\text { taxpayer is subject to } 4: 1 \text { DER } \\
\text { rule } \\
\text { 5axpayers whose whole income is } \\
\text { subject to final tax } \\
\text { Taxpayer who run infrastructure } \\
\text { industry. }\end{array}$ \\
\hline Effective since 8 Oct 1984 & Effective since 8 Oct 1984 & $\begin{array}{l}\text { Effective since } 9 \text { September } 2015 \text { and } \\
\text { revoke the former regulation }\end{array}$ \\
\hline
\end{tabular}


For tax calculation purpose, Article 1 Par (2) PMK-169 defined debt as the average outstanding of debt within one fiscal year or part of it. The calculation based on: (i) average outstanding balance at every end of month in corresponding fiscal year; or (ii) average balance at every end of month in corresponding part of fiscal year. The reason behind these criteria is to retain the ratio stabile through the year. Then, Article 1 Par (3) mentioned that outstanding balance include balance of long term and short-term debt also trade payable which bear interest to all institution regardless the related party. This article in intended to prevent back to back loan scheme. In addition, loan without interest obligation got from related party is treated as capital equity injection to prevent hybrid financial instrument practice. On the other hand, Government Regulation No 94/2010 regarding Calculation of Taxable Income and Settlement of Income Tax in Current Year, Article 12 Par (1) mentioned that debt financing without interest payment is allowed if the loan get form the shareholder on has paid up all of the capital and the business in on profit.

PMK-169 regulated that the ratio of debt to equity ratio (DER) for tax calculation is on the ration of $4: 1$. In fact, the fair formula which can describe the reality of business dynamic and the amount the interest should be paid as co-existence to determine the amount of debt to equity is not simple. For most of the countries, several industrial exceptions implementing the formula such as banking and financial sector apply (refer to Table 1). In addition, Article 3 (1) also regulated that borrowing cost expenses bear by taxpayer for funds borrowing include:

a. borrowing interest;

b. discount and premium related to borrowing;

c. additional expenses related to arrangement of borrowings;

d. finance charges in lease funding;

e. compensation for loan repayment guarantee; and

f. forex difference as result of foreign currency borrowings as long as such amount came from adjustment in interest expenses and expenses as mentioned in letter b, c, d, and e.

The described criteria on PMK-169 seems refer to "gross interest expenses" concept as introduce by OECD since it considers borrowing expenses as a package of interest expenses, including, for example the arrangement fees or other types of fees needed to get the money [6]. Further, under this regulation, borrowed fund from related party or under common control relation, intra-group loan should be treated as if the borrowing has been earned from independent party. Thus, transfer pricing rule with the arm's length principle applies to ensure the fairness of interest payment and to analyze the equity structure as determined by prevailing regulation.

Then, another question raised whether the implementation of PMK-169 has been appropriate and fair enough for business and for the government. The fact has shown that it is very relative. The existence of PMK-169 has allows the business to earn equity from debt financing on large proportion. The government premises are to ease the business expand without preventing them to obtain huge equity, similar reason behind the revoking KMK1002. It needs to highlight that the valid reason and the logic as the premises of PMK-169 released has not been widely published. The following part is the assessment of debt to equity practice on several industry performed by listed company in Indonesia Stock Exchange. The equity characteristic of listed and non-listed entity might be different since both has different obligation of business performance disclosure into the public. The distribution of sectors based on Indonesia Stock Exchange classification would be as table 3 . 
Table 3. The Debt-to-Equity Ratio Based on Industrial Sector and Distribution of Sectoral Business

\begin{tabular}{|c|c|c|c|c|}
\hline No & Type of Industry & Number of entities & Percentage & $\begin{array}{l}\text { Average DER } \\
\text { (sample base) }\end{array}$ \\
\hline 1 & Agriculture & 65 & $4 \%$ & 1,66771 \\
\hline 2 & $\begin{array}{l}\text { Basic industry and } \\
\text { chemicals }\end{array}$ & 285 & $18 \%$ & 2,09644 \\
\hline 3 & $\begin{array}{l}\text { Industry for } \\
\text { consumer goods }\end{array}$ & 145 & $9 \%$ & 1,26656 \\
\hline 4 & $\begin{array}{l}\text { Infrastructure and } \\
\text { transportation }\end{array}$ & 150 & $9 \%$ & 0,36644 \\
\hline 5 & Mining & 145 & $9 \%$ & 3,18398 \\
\hline 6 & Miscellaneous & 180 & $11 \%$ & 3,18398 \\
\hline 7 & $\begin{array}{l}\text { Property, real estate } \\
\text { and construction }\end{array}$ & 230 & $15 \%$ & 1,15639 \\
\hline 8 & Trade and services & 390 & $25 \%$ & 1,553659 \\
\hline Total & & 1590 & $100 \%$ & \\
\hline
\end{tabular}

Source: Indriasari (2015) [19]

The table 3 above shows that the largest proportion shares of business sector listed in Indonesia Stock Exchanges is trade and services, followed by basic industry and chemicals, property, real estate and construction. Other industry is seeming has quite similar proportion. The interesting fact presented on the table is that DER ratio of each industries has not been below the Indonesia DER rule, 4:1. The industry close to the threshold of Indonesia DER is mining industry then for others are still far below the threshold. Probably the status of listed company would be affected the contingency of each sectors. The situation probably would be different if the information presented is the data subtracted from the non-listed companies which the numbers are far large than the listed company.

\subsection{International Best Practices on the Rule of Debt-to-Equity Ratio}

\section{a. Thin Capitalization Rule in Australia}

A significant change to the Thin Capitalization Rules in Australia occurred in July 2001. This new provision rejects debt deductions for funds borrowed from shareholders ("controllers") if the debt to equity ratio is excessive. This provision applies to both foreign controlled Australian Companies, Branch or Associates (inbound) and Australian Entities that control foreign entities or operate abroad through Permanent Establishment (outbound). In applying this provision, an entity must be categorized in one of the eight categories of the entity, where each category of entity has its own provisions.

Debt Equity Ratio (DER) is applied to all debts including related party foreign debts and third-party debts. Included in the application of this DER is an agreement whereby an entity (including its associates) receives funds without any obligation to repay the same amount of funds invested. If the repayment period exceeds 10 years, the amount of funds invested in the discount to obtain the present value of the investment. While capital includes 
paid-up value of shares and share premium at the end of the year, as well as opening retained earnings and asset revaluations of assets held. Redeemable preference shares and participating or convertible debt are not included in the definition of debt but capital. Interest Free Debt does not include capital.

Based on Safe Harbor rules, interest deductions are limited by Debt to Equity Ratio in excess of $75 \%$ (Debt Equity 3: 1) and are subject to arm's length test. In addition, interest costs cannot be deducted as costs if The Australian operation exceeds $120 \%$ of the worldwide ratio group. The worldwide gearing test is only applied if Australian Debt Entity is not controlled by a foreign company. The ratio calculation uses the average foreign debt throughout the year compared to the capital owned. The excess interest and related financial charges ("debt deductions") cannot be charged as costs but are not recharacterized as dividends. Australia has its own provisions for financial institution.

\section{b. United Kingdom - Stand Alone Approach}

The close example on the implementation of stand-alone approach could be seen on United Kingdom thin capitalization rule. The thin capitalization rule shall apply to the related party debt applied by domestic entities or cross-border transaction undertaken by multinational corporation under European Court of Justice. Following the UK tax rule, the local borrower is treated as if it is an "independent" or stand-alone entity without considered that the entities has parent and sister company. This notional stand-alone and corporate group then are subjected to a transfer pricing analysis, this approach undertaken in order to ascertain the amount of money could be borrowed by each of them from financing entity or lender with the interest rate both the amount of debt that it could borrow from unrelated lenders and the interest rate that should be charged on this amount. This approach is the way of arm's length principle is applied even though the application is done with modification.

Further, under the UK taxation rule, no safe harbor provision should be applied, instead the subsidiary located in UK could be leveraged by the amount of financing debt from related party up to the maximum debt amount with the interest rate which the amount and rate can justify on an arm's length basis. This is rule applied for the entity regardless whether the multinational group of which it is part has third-party debt levels and interest costs of a similar proportion. However, the requirement to assume the stand-alone status/independent would be assumed, in most cases put some upper limit on the amount of debt that a hypothetical thirdparty lender would advance.

Tax policies vary by country in counteracting thin capitalization practices. Countries that implement a fixed ratio approach using a debt to equity ratio (DER) limited to affiliated debt can be seen in Table 4.

Table 4. Countries Applied DER Affiliated DER

\begin{tabular}{lcllllllll}
\hline Country & DER & Country & DER & Country & DER & Country & DER & Country & DER \\
\hline Argentina & $2: 1$ & Czech & $4: 1$ & Ghana & $2: 1$ & Macedonia & $3: 1$ & Poland & $1: 1$ \\
Belarus & $1: 1$ & Ecuador & $3: 1$ & Gibraltar & $5: 1$ & Mozambique & $2: 1$ & Rwanda & $4: 1$ \\
Brazil & $2: 1$ & Egypt & $4: 1$ & Kenya & $3: 1$ & Namibia & $3: 1$ & Slovenia & $4: 1$ \\
Chile & $3: 1$ & Salvado & $3: 1$ & Korea & $2: 1$ & Oman & $2: 1$ & Sri Lanka & $3: 1$ \\
& & r & & & & & & \\
China & $2: 1$ & France & $1,5: 1$ & Lithuania & $4: 1$ & Peru & $3: 1$ & Taiwan & $3: 1$ \\
Turkey & $3: 1$ & Uganda & $1,5: 1$ & US & $1,5: 1$ & Venezuela & $1: 1$ & Yemen & $7: 3$ \\
\hline
\end{tabular}

Source: R. d. Mooij and S. Hebous (2017) 
Following the Indonesian rule and compare to international best practice of DER which apply the 'accumulated debt', Indonesia seems still on moderate range. The Indonesia DER ratio is still same with Albania, Croatia, Denmark and Latvia. However, it needs to assess yearly whether that ratio is still appropriate to Indonesia taxation arena, especially for non-listed companies. The following Table 5 will present the information of countries which has applied DER with accumulated debt rule.

Table 5. Countries Applied DER Accumulated Debt

\begin{tabular}{lcllllllll}
\hline Country & DER & Country & DER & Country & DER & Country & DER & Country & DER \\
\hline Albania & $4: 1$ & Croatia & $4: 1$ & Hungary & $3: 1$ & NZ & $1,6: 1$ & Zimbabw & $3: 1$ \\
Australia & $1,5: 1$ & Denmark & $4: 1$ & Indonesia & $4: 1$ & PNG & $2: 1$ & & \\
Bulgaria & $3: 1$ & Dominican & $3: 1$ & Japan & $3: 1$ & Romania & $3: 1$ & & \\
Colombia & $3: 1$ & Georgia & $3: 1$ & Latvia & $4: 1$ & Serbia & $4: 1$ & & \\
& & & & & & & & & \\
\hline
\end{tabular}

Source: R. d. Mooij and S. Hebous (2017)

\section{Conclusion}

Based on the results and discussion, it can be concluded that the tax provisions in Indonesia have been equipped with restrictions on the imposition of interest to prevent the practice of tax avoidance through thin capitalization schemes. Indonesia applies two approaches at once, namely the fix ratio approach and the arm's length principle approach. The fixed ratio approach chosen in the current Indonesian regulation is based on a financial position statement (balance sheet) approach, namely by setting a debt to equity ratio (DER) of 4: 1 .

The arm's length principle approach is applied only if the debt originates from a related party. The use of these two approaches is relevant given the differences in characteristics between transactions that are influenced by special relationships with independent transactions. In transactions that are affected by a special relationship, the DER can occur naturally but the interest rate is not reasonable. Then the cost of loans for debts to parties that have a special relationship must also meet the arm's length principle.

The DER of listed companies in Indonesia Stock Exchange for most of sectors are still below the Indonesia DER threshold, with mining industry is close to the threshold. In addition, Indonesia DER also is still moderate compare to other countries which adopt the similar approach. For further study, it needs to assess the non-listed companies to assess whether the Indonesia threshold is still appropriate to apply by considering the current fact of DER applied by non-listed companies.

\section{References}


[1] Media Indonesia, "Perusahaan Mengaku Rugi tapi Terus Ekspansi (1)," Media Indonesia, 25 April 2016. [Online]. Available: https://mediaindonesia.com/read/detail/42193-perusahaanmengaku-rugi-tapi-terus-ekspansi-1. [Accessed 10 October 2019].

[2] A. Aditya, "BKPM Ancam Cabut Izin Perusahaan Asing Pengemplang Pajak," bisnis.com, 29 March 2016. [Online]. Available: https://ekonomi.bisnis.com/read/20160329/10/532545/bkpmancam-cabut-izin-perusahaan-asing-pengemplang-pajak. [Accessed 20 August 2019].

[3] V. W. S, Improper Use of Tax Treaties, London: Kluwer International, 1998.

[4] Gunadi, Transfer Pricing: Suatu Tinjauan Akuntansi, Manajemen dan Pajak, Jakarta: PT. Bina Rena Pariwara., 1998.

[5] B. P. H., "The Debt-Equity Debt-Equity Conundrum - A Prequel," Bulletin for International Taxation, vol. 66, no. 4/5, 2012.

[6] OECD, "Limiting Base Erosion Involving Interest Deduction and Other Financial Payments, Action 4-2015 Final Report, OECD/G20 Base Erosion and Profit Shifting Project," OECD Publishing, Paris, 2015.

[7] M. Sornajah, The International Law on Foreign Investment, 2 penyunt., Cambridge: Cambridge University Press, 2004.

[8] R. Flannigan, "Debt-Equity Distinction, Banking and Finance Law Review," SSRN, p. 2, 2011.

[9] D. R. Ames, "Debt-Equity Financing Guidelines: Capital Problems for Closely Held Businesses," Fordham Urban Law Journal, vol. 9, no. 4, pp. 1020-1038, 1981.

[10] D. Luthi, "Thin Capitalization of Companies in International Tax Law," Intertax, vol. 19, no. 10, pp. 446-453, 1991.

[11] N. Rahayu, "Evaluasi Regulasi atas Praktik Penghindaran Pajak Penanaman Modal Asing," Jurnal Akuntansi dan Keuangan Indonesia, vol. 7, no. 1, pp. 61-78, 2010.

[12] OECD Report, "Report on Thin Capitalization," OECD Publication, 1987.

[13] J. Blouin, H. Huizinga, L. Laeven and G. Nicodeme, "Thin Capitalization Rules and Multinational Firm Capital Structure," IMF Working Paper WP/14/12, 2014.

[14] R. d. Mooij and S. Hebous, "Curbing Corporate Debt Bias," IMF Working Papers, 2017.

[15] C. Burnett, "Intra-Group Debt at the Crossroads: Stand-Alone versus Worldwide Approach," World Tax Journal, vol. 6, no. 1, pp. 40-76, 2014.

[16] E. Traversa, "Interest Deductibility and the BEPS Action Plan: nihil novi sub sole?," British Tax Review, vol. 2013, no. 5, pp. 607-619, 2013.

[17] OECD, "Limiting Base Erosion Involving Interest Deductions and Other Financial Payments, Action 4 - 2016 Update: Inclusive Framework on BEPS," dalam OECD/G20 Base Erosion and Profit Shifting Project, Paris, OECD Publishing, 2016.

[18] Hartono, Analisis Penerapan Peraturan Mengenai Besarnya Perbandingan antara Utang dan Modal (Debt-to-equity) untuk Keperluan Penghitungan Pajak di Indonesia, Jakarta: Universitas Indonesia, 2014.

[19] N. T. Indriasari, Pengaruh Debt-to-equity ratio, Operation, Leverage dan Firm Size terhadap Imbal Hasil Perusahaan Non Keuangan di Bursa Efek Indonesia 2009-2015, Jakarta: Universitas Indonesia, 2015. 